水文・水源学会誌

J. Japan Soc. Hydrol \& Water Resour. \begin{tabular}{ll} 
Vol. 7. No. 3 (1994) & PP. 188-195 \\
\hline
\end{tabular}

\title{
Knowledg-Based Decision Support System of Real-Time Reservoir Operation for Drought Control
}

\author{
眝水池の実時間渴水操作に関する知識べース型意志決定支援システム
}

\author{
Toshiharu KOJIRI* \\ 小尻利治 \\ Kunio TOMOSUGI** • Carlos V. GALVAO** \\ 友杉邦雄 \\ カルロス V. ガルバオ \\ (Faculty of Eng., Gifu Univ.) \\ 岐阜大学工学部 \\ (DPRI Kyoto Univ.) \\ 京都大学防災研究所
}

The real-time reservoir operation is carried out under considerations of similar hydrograph and it's drought severity. In this paper, we will propose the decision support system through knowledge base and fuzzy inference. Discharge is predicted by combining long-term weather forecast and hydrograph similarity. Basic operation rules for drought is extracted through classified hydrographs and divided storage volume. Moreover, depending on the controlled performance, the reservoir operator can change the saving rate (release) through fuzzy inference.

Key words: reservoir operation, expert system, long-term weather (precipitation) forecast, fuzzy inference

渴水時の眝水池操作は、過去の類似流況を参考に渴水強度の推定と節水率 (放流量) の決定を行っている。本研究では、そうした 意志決定に際して、精度は低いが贵重な情報である長期気象 (降水) 予報と現行の類似流況とを結合させた合理的な支嗳システムを 提菜するものである。長期予報と統計值を用いた 1 ケ月先まての流量と代表流況に対する類似度を組み合わせて、流況予測を行う。 また、分類された流沇と眝水量の組み合わせに対して、竞切な貯水池操作を知識として求めて招き、ファジイ推論によって節水率(放 流量)を決める。最後に、毎時間の制御での達成度に応じて操作レベルの変更を加え、より理解し易い支授システムとするものであ る。

キーワード：貯水池操作、エキスパートシステム、長期気象（降水）予報、ファジイ推詥

\section{I . INTRODUCTION}

Recently we have been suffering from serious drought in Japan because of the unsteady water supply due to climate change, the rapid increase of water usage for urbanization and the concentration of population. To protect such situation, the operator at reservoir control office is requested the rational operation to save the water and perform the storage capacity. However, as the prediction accuracy for future weather is not sufficient, the reservoir is controlled through fixed rule which does not handle the forecast of hydrograph and the optimization of release. The actual release or saving rate of storage reservoir is decided among the concerned authorities obeying it's operation rules in proportion to inflow. So, as the results with this rule are not expected the effective release for all hydrographs, the unfixed adaptive control policy is requested.

In this paper, the authors will propose the real -time reservoir operation procedure combining

\footnotetext{
"Dept. of Civil Eng., Faculty of Eng., Gifu. Univ, 1-1 Yanagido, Gifu, Japan, 501-11

岐鼻大学工学部土木工学科 $=501-11$ 岐阜市楖戸 $1-1$

*"Water Resources Research Canter, DPRI, Kyoto Univ., Gokasho, Uji, Japan, 611

京都大学防災研究所水資源研究センター $=611$ 宇治市五ケ庄
} 
the long-term weather forecast, the similarity of hydrograph and the fuzzy inference. Meteorological Bureau in Japan announces the long-term (three months), the middle-term (one month) and the short-term (one week) forecast of precipitation in logic term though these accuracies are very low. Therefore, introducing the pattern recognition theory, the fuzzy theory and the expert concept, we structure the integrated system with forecast of inflow sequence for one month and reservoir operation for drought control.

\section{OPERATION PROCEDURE FOR LOW FLOW CONTROL}

To perform the effective storage capacity, let's consider three factors for low flow control; namely (i) inflow sequence until the present time, (ii) predicted inflow sequence for one month, and (iii) present storage volume [Kojiri et al, 1992]. From a viewpoint of analogy of reservoir operation against the knowledge-based expert system

[Ueno, 1987], the total system is divided into the following four sub-systems;

i) Knowledge base

Basic information on reservoir operation and analyzed information such as classified hydrographs, the prediction model for long-term forecast and the saving rules against storage volume are saved in computer. Necessary data is extracted from data base and treated for the specific purpose. In the case of extraordinary flood, an operation rule effective in one reference point may lead the extreme damage to other points. Such conflicts between operation rules are solved here.

ii ) Rule base

Knowledge for reservoir operation is rewritten as the simple operation rules expressed with IF -THEN form. Simplifying and condensing rules in knowledge base are carried on.

iii) Inference engine

The rational release or the saving rate is decided through the mathematical methodologies such as dynamic programming or fuzzy inference.
Proper inference process is applied according to the styles of design operation or real-time operation.

iv) User Interface

Comparing the calculated release and the denoted release with fixed rule, the operator have to decide the actual one to protect the water shortage in not only present time but also future. Furthermore, the explanation process is important to persuade the non-expert operator to accept the calculated release. In other words, the graphic or multi-media user interface will be taken in future.

Figure 1 shows the flow chart of operation, where in the knowledge base the similar observed discharge sequence is evaluated and one month ahead discharge is predicted. The hydrograph to be controlled is extracted according to the predicted result of long-term forecast. Moreover, depending on the predicted accuracy level, the performance level of control, the present storage level or one month ahead storage level, the operator takes the additional tuning operation as the changing level of release. Then, the final release or the saving rate is calculated. Knowledge base is handled in main frame computer because of much data and necessary memories. On the other hand, the real-time operation system is structures in work station or personal computer for emergency usage at isolated place.

\section{PREDICTION OF DISCHARGE}

\section{Prediction through short and middle -term forecast}

When the short-term (weekly) forecast is assumed to be announced at the previous day of the analyzed periods (five days), the precipitation for the considered periods is predicted as follows;

Step 1: As the precipitation of weekly forecast is expressed as logical level such as small, normal or big, the averaged precipitation (avp) is calculated by using the forecasted weather level and the historical one. 


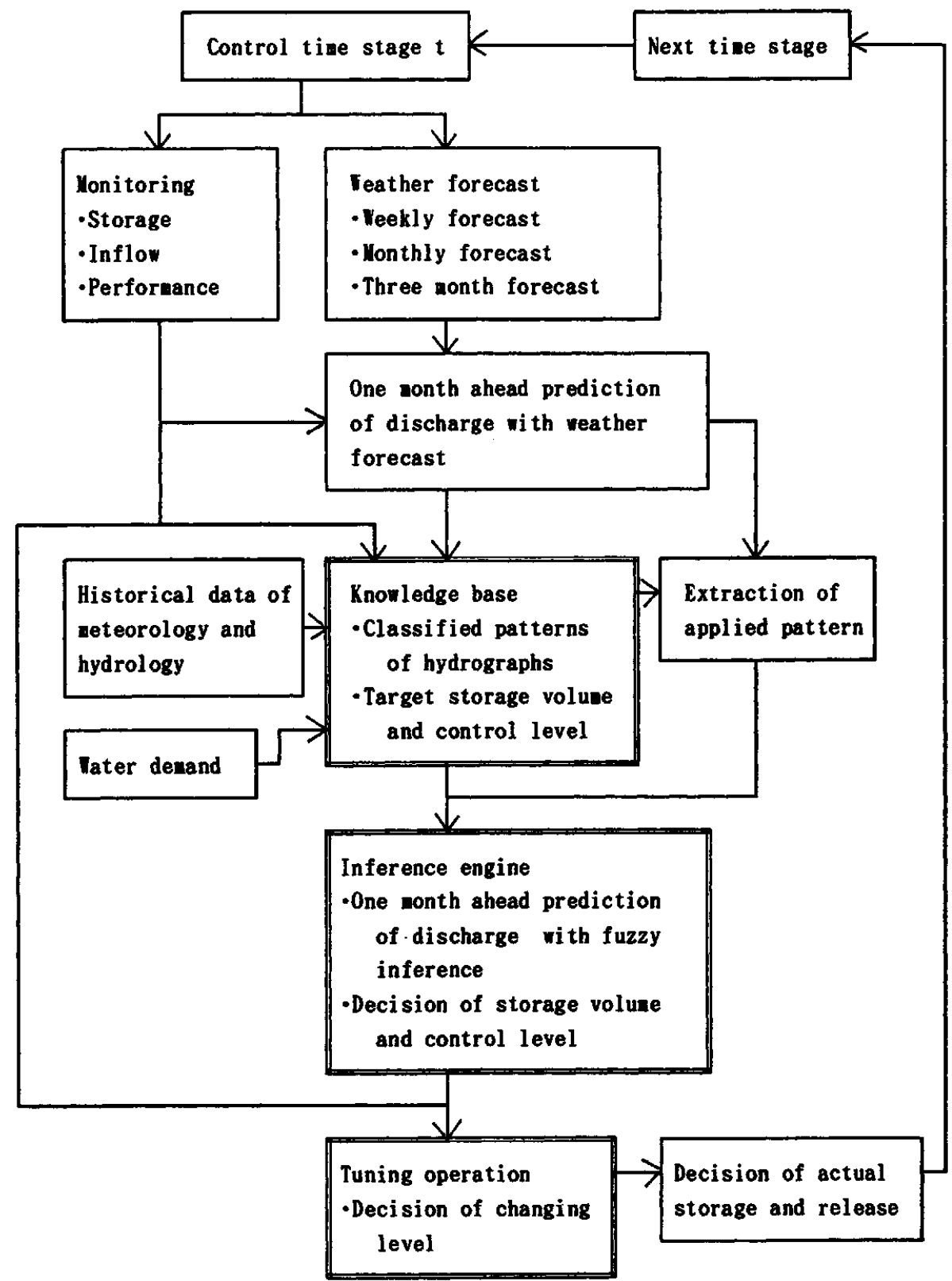

Figure 1 Operation procedure of storage reservoir for drought

If weekly forecast at one control period is announced as "normal", the averaged precipitation for a week is calculated as the averaged value between statistical boundary values of "big-normal" and "normal-small" as $32.2 \mathrm{~mm}$. As "normal" covers the precipitation range from $20 \%$ to $120 \%$, the averaged cover rate is

\section{7 .}

Step 2: From the observed weather situation, the numerical point of precipitation is accounted, where weather condition of "fine", "cloud" and "rain" are estimated with the value of " 0 ", " 1 " and " 2 ", respectively.

When the weather situation for considered 
week is "fine", "cloud", "cloud and some rain", "cloud after rain", "fine after cloud", "rain", "fine and some cloud" for each day, the numerical points are given as $0.0,1.0,1.5$, $2.0,1.5,0.5,0.5$.

Step 3: The tentative precipitation per point is calculated for observed precipitation in present week.

$$
\begin{aligned}
& 1 /(0.0+1.0+1.5+2.0+1.5+0.5+0.5) \times \\
& (0.7 \times 32.2)=3.2(\mathrm{~mm} / \text { point })
\end{aligned}
$$

Step 4: The tentative precipitation $(t r p)$ is converted into the representative one for the considered control periods.

Five days tentative precipitation is calculated as

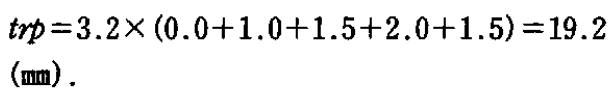

Step 5: The representative precipitation rate $(r p r)$ is obtained from the representative precipitation divided by averaged one.

If the averaged precipitation at considered period is $52.2(\mathrm{~mm})$, the precipitation rate is obtained as

$$
r p r=19.2 / 52.2=0.367 \text {. }
$$

Step 6: The representative precipitation rate in step 5 is described with precipitation level.

$36.7 \%$ is located in the range of "normal". Step 7: The predicted precipitation rate $(p p r)$ is estimated.

$$
p p r=(20+120) / 2=70(\%)
$$

Step 8: The precipitation $(p p v)$ is calculated with multiplying the historically averaged one with precipitation rate.

$$
p p v=52.2 \times 0.7 \times 36.54(\mathrm{~mm})
$$

Here, the calculation periods consist of five days. The precipitation is predicted until the end of the considered month from middle-term forecast following the same steps iteratively. Therefore the discharge sequence for one month ahead is obtained with application of run-off model to the precipitation [Ikebuchi and Kojiri, 1991]. For instance, the following linear regression model can be applied.

$$
Q I(t)=a_{1} Q I(t-1)+a_{2} r(t-1)+a_{3} r(t)+a_{4}
$$

Here, $Q I(t)$ is the predicted discharge at time $t$, $r(t)$ is the observed precipitation and $a_{1}$ ( $i=$ $1, \ldots, 4)$ is the parameter.

\section{2 . CLASSIFICATION OF HYDROGRAPHS}

Traditionally the discharge sequence in drought has been evaluated with it's severity from the similarity against the historical ones. As we have much data, the historical hydrographs are classified into several representative feature patterns on basis of their drought characteristics. The objective function for classification is formulated as follows;

$$
O F a(X(i), Z(j))=\max _{t}\left\{\frac{|x(i, t)-z(j, t)|}{z(j, t)}\right\}
$$

Here $x(i, t)$ is the discharge of sample pattern $i$ at time $t, z(j, t)$ is the discharge of representative pattern (cluster center in pattern recognition) $j$, and $X(i)$ and $Z(j)$ denote the vectors of hydrograph $i$ and $j$. Eq. (1) emphasizes the difference of low part of discharge for drought. Random K-means [Ismail and Kamel, 1986] and ISODATA methods [Tou and Gonzalez, 1974] can be applied to classify the historical hydrographs into the converged patterns [Kojiri et al., 1990]. From the long-term forecast, the precipitation at time $t, t+1$ and $t+2$ are obtained as the logical level of "small", "normal" or "big". After converting the averaged level of forecasted precipitation into discharge and comparing the discharge sequences between the long-term forecast and the hydrograph pattern, we must check the predicted accuracy with the criteria that difference of more than one logical level is not useful. The predicted hydrograph may be dismissed because of no up-dated pattern and low accuracy for the considered drought.

\section{IV . CONTROL RULES FOR DROUGHT}

The saving rate of storage reservoir is decided under the following assumptions;

(i) Saving water is not taken over three months, that is nine periods, because the drought 
situation should not be extended in future.

(ii) The saving rate at the future periods is not severer than that at the present time.

(iii) The saving rate in the continuous periods can not be changed into twice severer than that in the present situation.

(iv) The same saving level does not continue

Table 1 Saving rate of release for drought

\begin{tabular}{|c|c|c|c|c|c|c|c|c|c|}
\hline \multirow[b]{2}{*}{ Rule No. } & \multicolumn{9}{|c|}{ Saving rate at drought periods $(\times 10 \%)$} \\
\hline & 1 & 2 & 3 & 4 & ${ }_{5} p$ & $\begin{array}{c}\text { riod } t \\
6\end{array}$ & 7 & 8 & 9 \\
\hline 1 & 1 & & & & & & & & \\
\hline 2 & 1 & 1 & & & & & & & \\
\hline 3 & 2 & 1 & & & & & & & \\
\hline 4 & 2 & 1 & 1 & & & & & & \\
\hline 5 & 2 & 2 & 1 & & & & & & \\
\hline 6 & 3 & 2 & 1 & & & & & & \\
\hline 7 & 3 & 2 & 1 & 1 & & & & & \\
\hline 8 & 3 & 2 & 2 & 1 & & & & & \\
\hline 9 & 3 & 3 & 2 & 1 & & & & & \\
\hline 10 & 4 & 3 & 2 & 1 & & & & & \\
\hline 11 & 4 & 3 & 2 & 1 & 1 & & & & \\
\hline 12 & 4 & 3 & 2 & 2 & 1 & & & & \\
\hline 13 & 4 & 3 & 3 & 2 & 1 & & & & \\
\hline 14 & 4 & 4 & 3 & 2 & 1 & & & & \\
\hline 15 & 5 & 4 & 3 & 2 & 1 & & & & \\
\hline 16 & 5 & 4 & 3 & 2 & 1 & 1 & & & \\
\hline 17 & 5 & 4 & 3 & 2 & 2 & 1 & & & \\
\hline 18 & 5 & 4 & 3 & 3 & 2 & 1 & & & \\
\hline 19 & 5 & 4 & 4 & 3 & 2 & 1 & & & \\
\hline 20 & 5 & 5 & 4 & 3 & 2 & 1 & & & \\
\hline 21 & 6 & 5 & 4 & 3 & 2 & 1 & & & \\
\hline 22 & 6 & 5 & 4 & 3 & 2 & 1 & 1 & & \\
\hline 23 & 6 & 5 & 4 & 3 & 2 & 2 & 1 & & \\
\hline 24 & 6 & 5 & 4 & 3 & 3 & 2 & 1 & & \\
\hline 25 & 6 & 5 & 4 & 4 & 3 & 2 & 1 & & \\
\hline 26 & 6 & 5 & 5 & 4 & 3 & 2 & 1 & & \\
\hline 27 & 6 & 6 & 5 & 4 & 3 & 2 & 1 & & \\
\hline 28 & 6 & 6 & 5 & 4 & 3 & 2 & 1 & 1 & \\
\hline 29 & 6 & 6 & 5 & 4 & 3 & 2 & 2 & 1 & \\
\hline 30 & 6 & 6 & 5 & 4 & 3 & 3 & 2 & 1 & \\
\hline 31 & 6 & 6 & 5 & 4 & 4 & 3 & 2 & 1 & \\
\hline 32 & 6 & 6 & 5 & 5 & 4 & 3 & 2 & 1 & \\
\hline 33 & 6 & 6 & 5 & 5 & 4 & 3 & 2 & 1 & 1 \\
\hline 34 & 6 & 6 & 5 & 5 & 4 & 3 & 2 & 2 & 1 \\
\hline 35 & 6 & 6 & 5 & 5 & 4 & 3 & 3 & 2 & 1 \\
\hline 36 & 6 & 6 & 5 & 5 & 4 & 4 & 3 & 2 & 1 \\
\hline 37 & 6 & 6 & 5 & 5 & 4 & 4 & 3 & 2 & 2 \\
\hline 38 & 6 & 6 & 5 & 5 & 4 & 4 & 3 & 3 & 2 \\
\hline 39 & 6 & 6 & 6 & 5 & 5 & 5 & 4 & 4 & 4 \\
\hline 40 & 7 & 7 & 7 & 6 & 6 & 6 & 5 & 5 & 5 \\
\hline 41 & 8 & 8 & 8 & 8 & 8 & 8 & 8 & 8 & 8 \\
\hline
\end{tabular}

over three periods.

( $v$ ) The severest level of saving rate is seven where three-tenth volume against water demand is supplied.

If the same saving levels at the considered period but the different saving sequence are denoted, the saving rule with which severer level will be accepted at the continuous period is used. Adding three control rules with the severest saving rate for extraordinary drought, we extracted forty-one rules among one hundred and eight combinations plus three rules shown in Table 1. The control rules are represented as IF-THEN form in the rule base as follows;

IF $h y$ is $H Y(j)$ and $s$ is $S(k)$, THEN qo is $Q O(j, k)$ or $s^{\prime}$ is $S^{\prime}(j, k)$

where $h y$ is the present discharge sequence (a part of hydrograph), $s$ is the observed storage volume, qo is the release (water supply from reservoir) and $s^{\prime}$ is the storage volume at the continuous time stage. $Q O(j, k)$ and $S^{\prime}(j, k)$ are the known optimal release and storage volume in the case of hydrograph $H Y(j)$ and storage volume $S(k)$ satisfying water demand for normal situation and designed saving rate for specified drought period. For each representative hydrograph at each time stage and for each discretized storage volume, the feasible saving rate is calculated. If reservoir has calculated storage volume, water storage is forecasted under the conditions of classified hydrograph and saving rate for the specific periods. Beyond one year the normal water demand and supply are assumed to be repeated.

\section{REAL-TIME RESERVOIR OPERA- TION}

\section{Decision of saving rate}

As the observed data is not equal to the defined values in knowledge base because of uncertainty and limited definition, the release or the storage volume can be calculated through the fuzzy inference theory. The similarities of antecedent is defined as follows; 


$$
\begin{aligned}
& F d 1(q(t))=\max _{t}\{|q(t)-z(j, t)| / z(j, t)\}(4) \\
& F d 2\left(q^{\prime}(t)\right)=\max _{t}\left\{\left|q^{\prime}(t)-z(j, t)\right| / z(j, t)\right\}(5) \\
& F d s(s)=\max \left\{a S_{\mathrm{k}}-\left|s-b S_{\mathrm{k}}\right| / a S_{k}, 0\right\}
\end{aligned}
$$

Where, $q(t)$ is the observed discharge, $q^{\prime}(t)$ is the predicted discharge, $a S_{k}$ and $b S_{k}$ are the parameters of the fuzzy membership functions and $k$ is equal to the combination number of operation rules derived from the divided fuzzy spaces of hydrograph and storage volume. The fidelity is obtained through the averaging method as follows;

$$
\begin{aligned}
& W a_{k}=\left\{\operatorname { m i n } \left(F d 1(q(t)), F d 2\left(q^{\prime}(t)\right)\right.\right. \\
& +F d s(s)\} / 2
\end{aligned}
$$

Then the membership functions of consequent is represented by overlaying the membership functions $F 0(r e)$ on release $r e$, which is cut with the grade of fidelity as follows;

$$
B 0(s r)=\{V(F 0(r e)\}
$$

Here, $V$ denotes the fuzzy sum algorithm and $s r$ means the co-ordinate of saving rate. For defuzzification the value $S R$ is decided as the gravity center of membership function $B 0(s r)$ as follows [Sugeno, 1988] ;

$$
S R=\frac{\int B 0(s r) s r d s r}{\int B 0(s r) d s r}
$$

\section{TUNING OF SAVING RATE}

According to the performance of reservoir operation, we want to change the control level depending on forecast accuracy or previous performance. The factors for changing level are defined as follows;

(i ) Future conditions: one month ahead storage volume $(F s)$ and accuracy $(F a)$

(ii) Present condition: Present storage volume $(P s)$ and gradient of storage $(P g)$

(iii) Performance: difference between target storage and observed storage volume $(P p)$

As little storage or low accuracy gives us the anxiety of control results, we can save more water for coming drought. The changing level is represented by the following IF-THEN form;

$$
I F \text { ( } F s \text { and } F a \text { ) or }(P s \text { and } P g \text { ) or }(P p) \text {, }
$$

THEN Col

After defining the membership functions as Figure 2, we obtain the fidelity of antecedent as follows;

$$
\begin{aligned}
& f t o=\max \left\{\min \left(f_{s}(F s), f p(F a)\right), \min \right. \\
& (f s(P s), f d(P g)\}, f(P p))\}
\end{aligned}
$$

As Table 2 shows the changing levels for the combination of operational factors, the final changing level is decided through the fuzzy inference as follows, too;

$$
f c l=\frac{\Sigma f t o_{u} \mathrm{Col}_{u}}{\Sigma \mathrm{fto}_{u}}
$$

where, $u$ denotes the combination number of antecedent factors on changing levels.

\section{APPLICATION OF PROPOSED METHODOLOGIES TO REAL BASIN}

The basic information on applied reservoir is listed below;
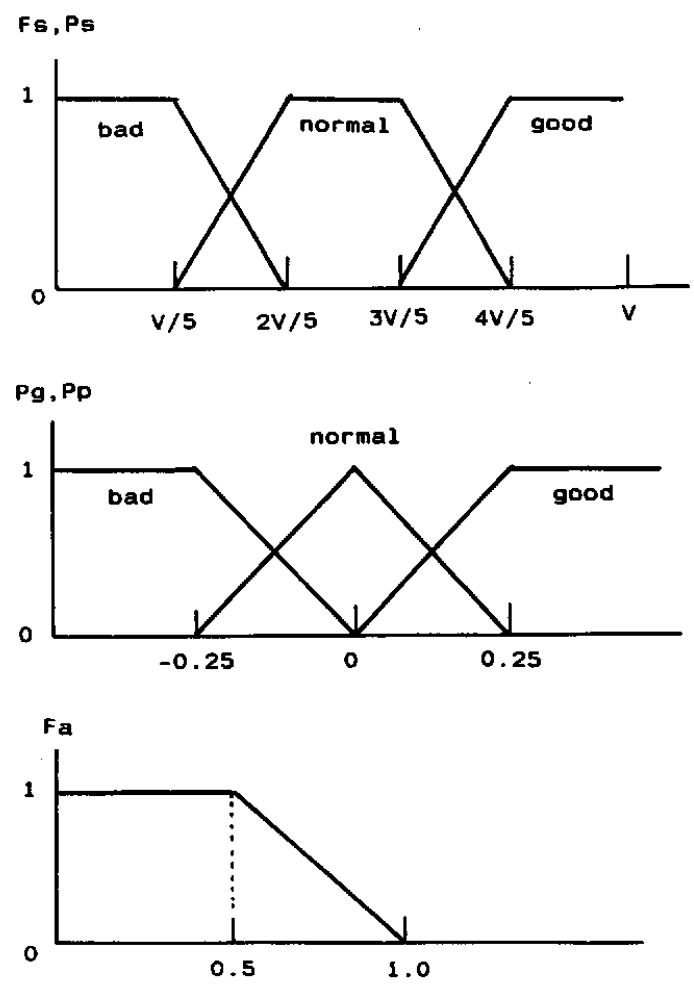

Figure 2 The membership functions on tuning operation 
Table 2 Tuning rules for changing level of release

\begin{tabular}{|c|c|c|c|c|}
\hline Rule No. & Future & Present & Performance & Changing level \\
\hline 1 & bad & bad & bad & +3 \\
\hline 2 & bad & bad & normal & +2 \\
\hline 3 & bad & bad & good & +1 \\
\hline 4 & bad & normal & bad & +2 \\
\hline 5 & bad & normal & normal & +1 \\
\hline 6 & bad & normal & good & 0 \\
\hline 7 & bad & good & bad & +1 \\
\hline 8 & bad & good & normal & 0 \\
\hline 9 & bad & good & good & -1 \\
\hline 10 & normal & bad & bad & +2 \\
\hline 11 & normal & bad & normal & +1 \\
\hline 12 & normal & bad & good & 0 \\
\hline 13 & normal & normal & bad & +1 \\
\hline 14 & normal & normal & normal & 0 \\
\hline 15 & normal & normal & good & 0 \\
\hline 16 & normal & good & bad & 0 \\
\hline 17 & normal & good & normal & 0 \\
\hline 18 & normal & good & good & -1 \\
\hline 19 & good & bad & bad & +1 \\
\hline 20 & good & bad & normal & 0 \\
\hline 21 & good & bad & good & 0 \\
\hline 22 & good & normal & bad & 0 \\
\hline 23 & good & normal & normal & 0 \\
\hline 24 & good & normal & good & 0 \\
\hline 25 & good & good & bad & 0 \\
\hline 26 & good & good & normal & -1 \\
\hline 27 & good & good & good & -1 \\
\hline
\end{tabular}

Storage capacity $43.0 \times 10^{6} \mathrm{~m}^{3}$

Number of sample inflows

twenty-three years

Water demand $\quad 15.0 \mathrm{~m}^{3} / \mathrm{sec}$ for municipal

$5.0 \mathrm{~m}^{3} / \mathrm{sec}$ for mainte. nance

$35.0 \mathrm{~m}^{3} / \mathrm{sec}$ for agriculture

(from 13-th to 21-th time)

one period of time stage

five days

Sample hydrographs are classified into five representative ones with ISODATA method as shown in Figure 3. Figure 4 shows the minimum target storage sequences for representative hydrographs. If reservoir has those storage level at every time stage, there should be no water shortage over a year on such a hydrograph. Figure 5 shows the applied results of drought control for unknown hydrograph. The reservoir could be controlled to avoid the big damage for drought. From the tuning control, the reservoir was requested to have more water. The reason is that the predicted accuracy of middle and long-term forecast were too low and the operator had to be anxious of control results under his responsibility. Considering the information from this system as a warming to change his operational strategy, he could control the drought safely and perform the storage capacity.

\section{CONCLUSIONS}

In this paper, we proposed the decision support 


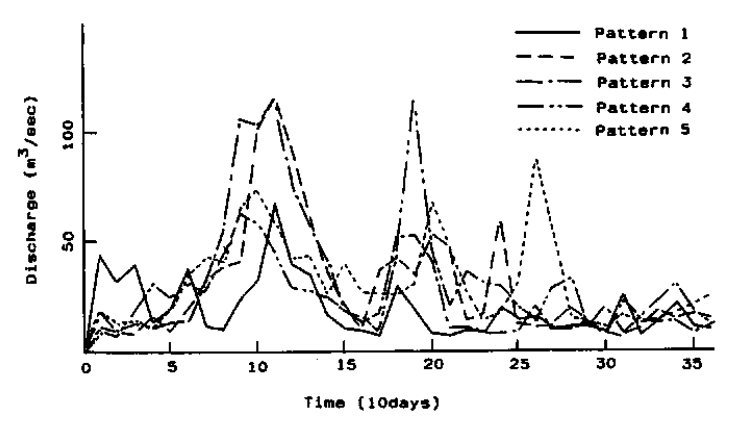

Figure 3 Classified hydrographs by considering whole shape and low flow

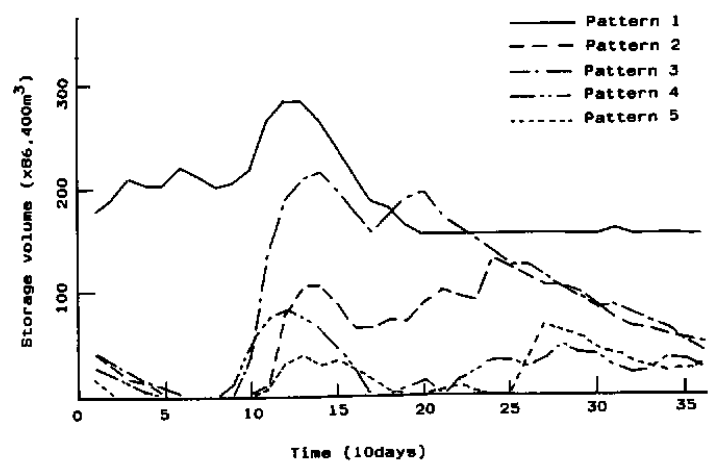

Figure 4 Target Storage sequences among classified hydrographs

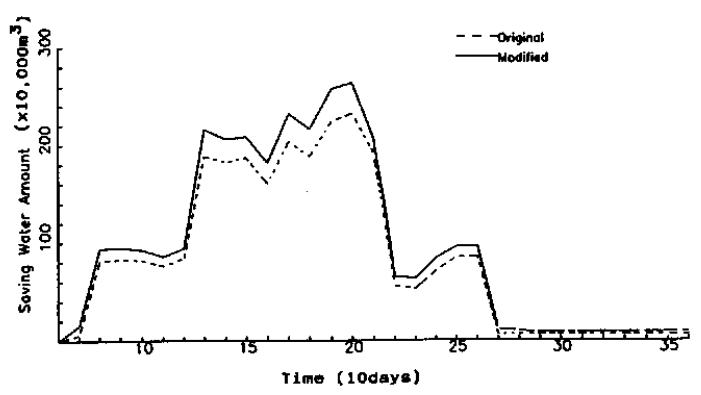

Figure 5 Comparison of storage sequences of basic operation and modified result with tuning operation

system of storage reservoir for drought control with the fuzzy theory. To sum up, the following results were obtained;

i) Short, middle and long-term weather fore- cast were used with their predicted accuracies.

ii) The effective operation procedures were established by combining their prior operation for representative hydrographs and updated inflow forecast.

iii) Adding the tuning operation to the basic system against accuracy and performance levels, the operator can get the non-anxious controlled results.

\section{REFERENCES}

1) Ikebuchi, S. and Kojiri, T. (1991): Real -Time Drought Control of Storage Reservoir by Combining Middle and Long-Term Weather Forecast and Fuzzy Inference, Application of Artificial Intelligence in Engineering VI, Computational Mechanics Publications, Elsevier Applied Science, pp. 531-548.

2) Ismail, M.A. and Kamel, M.S. (1989): Multidimensional Data Clustering Utilizing Hybrid Search Strategies, Pattern Recognition, Vol. 22, No. 1, pp. 75-89.

3) Kojiri, T. and Unny, T.E. (1990): Application of Pattern Classification Methodologies to Hydrological Data, Journal of JSHW, Vol.3, No. 3, pp. 53-59.

4) Kojiri, T., Unny, T.E. and Panu, U.S. (1992): Estimation and Management of Drought Situation by Using Pattern Classification and Fuzzy Inference, Proc. of 8th Congress, APD-IAHR, Vol. I, pp. A67-A78.

5 ) Sugeno, M. (1988): Fuzzy Control, Nikkan Kogyo Newspaper Company.

6) Tou, J.T. and Gonzalez, R.C. (1974): Pattern Recognition Principle, Applied Mathematics and Computation, No. 7, Addison Wesley Publishing Company, pp. 75-109

7) Ueno, H. (1987): Introduction to Knowledge Engineering, Ohm Publishing Company. (Received: 1993. 11. 20, Accepted: 1994. 1. 27) 